\title{
Changes in Cell/Tissue Organization and Peroxidase Activity as Markers for Early Detection of Graft Incompatibility in Peach/Plum Combinations
}

\author{
Olfa Zarrouk ${ }^{1}$ \\ Department of Pomology, Estación Experimental de Aula Dei (CSIC), Apartado 13034, 50080 \\ Zaragoza, Spain \\ Pilar S. Testillano and María Carmen Risueño \\ Plant Development and Nuclear Organization, Centro de Investigaciones Biológicas (CSIC), \\ C/Ramiro de Maeztu 9, 28040 Madrid, Spain \\ María Ángeles Moreno and Yolanda Gogorcena ${ }^{2}$ \\ Department of Pomology, Estación Experimental de Aula Dei (CSIC), Apartado 13034, 50080 \\ Zaragoza, Spain
}

\begin{abstract}
AdDitional INDEX WORDS. compatibility, cambium, union interface, isozyme profile, phenolic compounds
Abstract. Changes in cell and tissue organization and in peroxidase activity have been analyzed to find early markers to predict graft incompatibility occurrence in peach/plum combinations (Prunus persica/Prunus spp.) at 5 months after grafting in the dormancy period. Different compatible and incompatible peach/plum grafts were grown for 5 months in a nursery. The cellular study of the graft interface revealed structural changes associated with graft incompatibility symptoms. The main structural features were cambium cell disorganization, less differentiation of vascular tissues, degeneration of phloem and xylem cells, and accumulation of phenols at the graft interface after 5 months of graft development. The peroxidase study was performed during dormancy and the vegetative growth period, and revealed a significant increase in peroxidase activity in the incompatible unions, with significant differences between compatible and incompatible grafts. Analysis of gel profiles of nonbudded rootstocks and scions revealed an anodal isoperoxidase band [relative front $(\mathrm{Rf})=\mathbf{0 . 4 8}$ ] present in scions and compatible rootstocks, and another isoperoxidase band $(\mathbf{R f}=\mathbf{0 . 5 3})$ only present in the incompatible rootstocks. Our results show that the analysis of cell organization to detect early structural events and the evaluation of peroxidase activity at graft unions constituted feasible and convenient methods for early diagnosis of graft incompatibility. Also, it was suggested that the presence of band $\mathrm{Rf}=\mathbf{0 . 4 8}$ in plum rootstocks and peach cultivars could be used as a marker to predict graft compatibility for peach scions and plum rootstocks.
\end{abstract}

In the Mediterranean area, there is a widespread use of peach $\times$ almond hybrids (Prunus persica $\times$ Prunus dulcis) as peach rootstocks because they are tolerant and/or resistant to variety of biotic and abiotic stresses (Byrne et al., 1990; Felipe, 2009; Kester and Asay, 1986; Pinochet, 2009) and are generally graftcompatible with peach cultivars (Cambra, 1990; Moreno and Cambra, 1994; Moreno et al., 1994b). However, these rootstocks are known to be extremely vigorous (Wertheim and Webster, 2005; Zarrouk et al., 2005) and relatively sensitive to waterlogging (Okie and Weinberger, 1996). Because control of tree vigor is becoming a matter of increasing importance (Wertheim and Webster, 2005), and peach production is expanding to heavy soils, the use of plum rootstocks is a feasible solution (Beckman and Lang, 2003). Plum rootstocks are generally less vigorous (Moreno et al., 1995), and are more

Received for publication 16 Dec. 2009. Accepted for publication 26 Jan. 2010. Financial support was provided by Comisión Interministerial de Ciencia y Tecnología (project nos. AGL2005-05533 and AGL2008-00283/AGR, partially founded by BFU2008-00203 and AGL2008-04255), by the CONSID-DGA A 44, and by a fellowship granted to O.Z. from the Agencia Española de Cooperación Internacional (AECI).

We gratefully acknowledge Dr. Joaquim Miguel Costa and Dr. Victoria Fernández for critical reading for the manuscript.

${ }^{1}$ Current address: Instituto de Tecnologia Química e Biológica, Universidade Nova de Lisboa. Av. da República - EAN, 2780-157 Oeiras, Portugal.

${ }^{2}$ Corresponding author. E-mail: aoiz@eead.csic.es. tolerant to waterlogging (Rowe and Beardsell, 1973) and root knot nematodes [Meloidogyne spp. (Pinochet et al., 1999)]. They are also tolerant to calcareous soils (Gogorcena et al., 2004; Jiménez et al., 2008), and they provide the possibility to overcome replanting problems (Nicotra and Moser, 1997). However, many peach cultivars exhibit graft incompatibility when grafted onto some plum rootstocks (Moreno et al., 1994a; Zarrouk et al., 2006). Manifestations of peach/plum incompatibility appear generally during the first summer after grafting, although symptoms can also be delayed for several years (Moreno et al., 1993), and are typically evident by translocated incompatibility symptoms (Zarrouk et al., 2006). They are expressed by tree growth cessation and premature tree defoliation (Herrero, 1951) caused by a phloem dysfunction (Moing and Carde, 1988; Schmid and Feucht, 1981) and biochemical alterations at the graft interface (Moing et al., 1987). Otherwise, some peach/plum combinations can exhibit symptoms of localized incompatibility after several years without any other symptoms. These localized symptoms are characterized by anatomical irregularities at the union interface (Zarrouk et al., 2006) and with breaks in cambial and vascular continuity (Mosse, 1962). The abnormal functioning of the newly formed cambium causes an invagination of the cambial zone, a differentiation of parenchymatous tissue in the place of xylem (Deloire and Hébant, 1983; Gur et al., 1968), and a lack 
of lignification of cells interlocked at the graft union (Hartman et al., 2002). The peroxidase enzyme is associated with differentiating xylem (Sterjiades et al., 1993), as well as with lignification processes (Harkin and Obst, 1973). In addition, this enzyme was reported to be implicated in process related to graft establishment (Deloire and Hébant, 1982; Feucht et al., 1983; Schmid and Feucht, 1985). Higher peroxidase activity in grafted rootstocks was related to graft incompatibility in Prunus species (Rodrigues et al., 2002), and it has been suggested that differences in peroxidase concentration between rootstock and scion may cause bad vascular connections (Santamour, 1992). Graft incompatibility of peach rootstocks is an important characteristic to be assessed in breeding programs. Nevertheless, traditional evaluation is time consuming because appearance of physiological symptoms or anatomical anomalies may take 1 to several years (Moreno et al., 1993). Many studies were carried out to control graft incompatibility in peach/plum combinations (Breen, 1975; Moing and Carde, 1988; Moing and Gaudillère, 1992; Moing et al., 1987; Moreno et al., 1994a). However, few studies describe a method to detect early graft problems. Ermel et al. (1999) identified 13 variables that potentially discriminate compatible from incompatible grafts by a histological study on 5-month-old pear/quince combinations (Pyrus communis/ Cydonia oblonga). On the other hand, the peroxidase isozyme analysis of scion and rootstock to predict incompatibility before grafting was reported in chinese chestnut [Castanea mollissima (Santamour, 1988a)], red oak [Quercus rubra (Santamour, 1988b)], and pear (Gulen et al., 2002). When the peroxidase isozyme pattern of the scion matches with that of the rootstock, a graft resulted in a compatible union and in the restoration of vascular connection. In contrast, when it was different, callus formation was impaired and graft incompatibility occurred (Santamour, 1988c). Moreover, other studies with herbaceous species such as tomato (Solanum lycopersicum) show that peroxidase activity is implicated in the grafting process and that the enzyme is located mainly in the graft region (FernándezGarcía et al., 2004).

The main objective of this work was to assess in peach/plum combinations grafted with traditional methods the use of histological examination and to evaluate peroxidase activity and isozyme profiles in wood during dormancy, as early indicators associated with graft incompatibility.

\section{Materials and Methods}

Plant material for histological studies. Two plum rootstocks showing different graft compatibility performance with the exigent nectarine $(P$. persica) cultivar Summergrand were used: 1) one clone of 'Pollizo de Murcia' under selection: 'PM 105 AD' (Prunus insititia), compatible with 'Summergrand' and 2) 'Myrobalan GF 3-1' (Prunus cerasifera), incompatible with 'Summergrand'. Hardwood cuttings of the two plum rootstocks were propagated in a seed plot. The following winter (2003-04), rooted cuttings were transferred and established in a nursery. Budwood of the cultivar Summergrand and rootstocks were collected from the Prunus collection, maintained at the Aula Dei Experimental Station (Zaragoza, Spain), and were T-grafted in situ on the two rootstocks on 19 Sept. 2004. Three types of combinations were carried out: compatible homografts ('Myrobalan GF 3-1'/'Myrobalan GF 3-1' and 'PM 105 AD'/'PM 105 AD'), a compatible heterograft ('Sum-
mergrand'/'PM $105 \mathrm{AD}$ '), and an incompatible heterograft ('Summergrand'/'Myrobalan GF 3-1'). Grafts were collected on 17 Feb. 2005, $157 \mathrm{~d}$ after grafting (about 5 months later).

Histological EXAmination. Three graft unions per combination were collected and each stem piece $(3-5 \mathrm{~mm}$ in diameter) was cut transversally into four slices numbered from the upper part to the bottom $(1,2,3$, and 4). As a result, 12 slices per combination were obtained. Slices were fixed in $2.5 \%$ glutaraldehyde, containing $0.1 \%$ caffeine in $0.1 \mathrm{M}$ phosphate buffer ( $\mathrm{pH} 7.4$ ), for $4 \mathrm{~h}$ at $4{ }^{\circ} \mathrm{C}$, dehydrated in a graded ethanol series, and embedded in glycolmethacrylate resin Technovit 7100 (Heraeus Kulzer, Wehrheim, Germany) according to Ermel et al. (1999). For the light microscopy study, transverse semithin sections $(2 \mu \mathrm{m})$ were obtained with a Leica RM2135 microtome (Leica Instruments, Nussloch, Germany) equipped with a tungsten carbide knife. Sections were stained with $0.05 \%$ Toluidine Blue O (O'Brien et al., 1965). Sections were observed under a bright field in a light microscope (Ernst Leitz, Wetzlar, Germany) equipped with a digital camera (DP10; Olympus Europe, Hamburg, Germany).

Plant material and Methods for Peroxidase aCtivity. Two grafted combinations were used: 'Summergrand' grafted onto peach-based rootstocks and 'Summergrand' grafted onto plum-based rootstocks (Table 1). 'Summergrand' grafted on 'GF $677^{\prime}$ ' was used as standard of compatibility for peroxidase activity studies. The hardwood cuttings of rootstocks were grown in a seed plot during the winter. Rooted cuttings of rootstocks were established in a nursery the following winter and were T-grafted in situ with budwood of 'Summergrand' collected from the Prunus collection orchard in September. For each sample, graft union portion consisting on bark and cambium ( $2 \mathrm{~g}$ ) excised from the union zone of 4- to 5-monthold trees (January-February: dormant trees) and from 7- to 8month-old trees (April-May: first-growing vegetative station) were ground using a mortar and a pestle in liquid nitrogen. Ten milliliters of extraction buffer $(0.05 \mathrm{M}$ Tris citrate, $\mathrm{pH} 8.0,1$ $\mathrm{g} \cdot \mathrm{L}^{-1}$ citric acid, $1 \mathrm{~g} \cdot \mathrm{L}^{-1}$ ascorbic acid, $10 \mathrm{~g} \cdot \mathrm{L}^{-1}$ polyethylene glycol (PEG) 4000, and 0.8\% 2-mercaptoethanol) plus $1 \mathrm{~g}$ of polyvinylpolypyrrolidine (PVPP; Sigma-Aldrich, St. Louis) were then added to the frozen powder. The homogenization was made on ice at $4{ }^{\circ} \mathrm{C}$. Samples were then centrifuged at 6000 $\mathrm{g}_{\mathrm{n}}$ for $20 \mathrm{~min}$ at $4^{\circ} \mathrm{C}$ as described by Arulsekar and Parfitt (1986). The clear supernatant representing the enzyme extract was recovered.

Peroxidase activity was determined spectrophotometrically by following the increase in absorbance at $470 \mathrm{~nm}$ over $10 \mathrm{~min}$ in a spectrophotometer ultraviolet-2101PC (Shimadzu Scientific Instruments, Columbia, MD). The reaction mixture contained $50 \mathrm{mM}$ potassium phosphate, $\mathrm{pH}$ 6.8, $10 \mathrm{mM}$ hydrogen peroxide, $9 \mathrm{mM}$ guaiacol, and $20 \mu \mathrm{L}$ of enzyme extract in a total volume of $1 \mathrm{~mL}$, as described by Fernández-García et al. (2004). The mean value of at least three replications was taken as indicator of peroxidase activity.

DETERMINATION OF ISOPEROXIDASE PROFILE BY NATIVE POLYACRYLAMIDE GEL ELECTROPHORESIS (PAGE). Bark and cambium tissues were excised from current-year shoot growth of 'Catherina' and 'Summergrand' scions, as well as nonbudded Prunus rootstocks (Table 2), from 15-year-old trees established in the Prunus collection orchard of Aula Dei Experimental Station. Samples from three different plants were collected following the protocol described by Gulen et al. (2002). Other triplicate samples were also taken from the graft 
Table 1. Rootstocks grafted with 'Summergrand' nectarine for the peroxidase activity study.

\begin{tabular}{|c|c|c|c|}
\hline Rootstocks & Prunus species & Origin $^{z}$ & Compatibility $^{3}$ \\
\hline \multicolumn{4}{|l|}{ Peach-based rootstocks } \\
\hline ‘Cadaman $®$ Avimag' & $P$. persica $\times P$. davidiana & INRA, France & Compatible \\
\hline \multicolumn{4}{|l|}{ Plum-based rootstocks } \\
\hline 'Adesoto 101' & P. insititia & CSIC, Spain & Compatible \\
\hline 'PM 105 AD' & P. insititia & CSIC, Spain & Compatible \\
\hline 'Damas GF 1869' & $P$. domestica $\times P$. spinosa & INRA, France & Incompatible \\
\hline 'Krymsk-1' & P. tomentosa $\times P$. cerasifera & KEBS, Russia & Incompatible \\
\hline 'Marianna 2624' & P. cerasifera $\times P$. munsoniana & UC, USA & Incompatible \\
\hline 'Marianna GF 8-1' & $P$. cerasifera $\times P$. munsoniana & INRA, France & Incompatible \\
\hline 'Myrobalan GF 3-1' & $P$. cerasifera $\times P$. salicina & INRA, France & Incompatible \\
\hline
\end{tabular}

$\overline{{ }^{\mathrm{Z}} \mathrm{CNR}}=$ Centro Nacionale della Recerca, CSIC $=$ Consejo Superior de Investigaciones Científicas, INRA = Institut National de la Recherche Agronomique, KEBS = Krymsk Experimental Breeding Station, UC = University of California.

${ }^{y}$ Compatibility performance of rootstocks with 'Summergrand' nectarine.

Table 2. Cultivars and rootstocks used for the isoperoxidase profile study of bark tissues of non-budded plants.

\begin{tabular}{|c|c|c|c|}
\hline Rootstocks & Prunus species & Origin $^{z}$ & Compatibility $^{\mathrm{y}}$ \\
\hline \multicolumn{4}{|c|}{ Peach and nectarine cultivars } \\
\hline 'Summergrand' & P. persica & FA-RN, USA & - \\
\hline 'Barrier' & P. persica $\times P$. davidiana & CNR, Italy & Compatible \\
\hline 'Cadaman $®$ Avimag' & $P$. persica $\times P$. davidiana & INRA, France & Compatible \\
\hline 'GF 677' & $P$. dulcis $\times P$. persica & INRA, France & Compatible \\
\hline 'PM 105 AD’ & P. insititia & CSIC, Spain & Compatible \\
\hline 'Hiawatha' & P. besseyi $\times P$. salicina & USDA, USA & Compatible \\
\hline 'Ishtara ${ }^{\circledR}$ Ferciana' & $\begin{array}{c}(P . \text { cerasifera } \times P \text {. salicina }) \times \\
(P . \text { domestica } \times P \text {. persica })\end{array}$ & INRA, France & Compatible \\
\hline 'Jaspi® Fereley’ & (P. salicina $\times P$. cerasifera $) \times P$. spinosa & INRA, France & Compatible \\
\hline 'Myrobalan GF 3-1' & P. cerasifera $\times P$. salicina & INRA, France & Incompatible \\
\hline
\end{tabular}

${ }^{\mathrm{z}} \mathrm{CNR}=$ Centro Nacionale della Recerca, $\mathrm{CSIC}=$ Consejo Superior de Investigaciones Científicas, EM = East Malling Research Station, FA-RN $=$ F. Anderson, Merced, and Reedley Nursery (California), GB = Gregory Brother's (California), INRA = Institut National de la Recherche Agronomique, KEBS = Krymsk Experimental Breeding Station, NJAES = New Jersey Agricultural Experiment Station, UC $=$ University of California, USDA = U.S. Department of Agriculture.

${ }^{\mathrm{y}}$ Compatibility performance of rootstocks with 'Summergrand' nectarine.

unions of budded plants at approximately 5 months after grafting (Table 2). Protein extract was prepared as described for peroxidase activity. Isozyme separation analysis was carried out by electrophoresis in polyacrylamide gels. Gels were 0.75 $\mathrm{mm}$ thick with three layers: the spacer gel (4\% of acrylamide), the upper resolving gel (6.3\% of acrylamide), and the lower resolving gel ( $10 \%$ of acrylamide). Gel buffers for three layers and the tray buffer used were as described by Royo et al. (1997). Electrophoretic separation was carried out at $2 \mathrm{~mA}$ per well for 3 to $4 \mathrm{~h}$ at $4{ }^{\circ} \mathrm{C}$.

Gels were stained for peroxidase by 3-amino-9-ethyl carbazol solution $(10 \%, \mathrm{w} / \mathrm{v})$ according to Arulsekar and Parfitt (1986). Each band was identified by its relative front using $\mathrm{Rf}=$
1.0 , as the distance to the fastest band, and $\mathrm{Rf}=0.0$, as the starting point of the resolving gel, as it was described by Manganaris and Alston (1992). The Rf of bands was derived from mean values from at least three independent runs. Gels were scanned and photographs were taken, but they seldom showed all visible bands. Thus, zymograms were drawn from average $\mathrm{Rf}$ and intensity of bands. Bands that were not visible in the three runs were assumed as not detectable and are not included in this study.

Statistical analysis. Data were evaluated by analysis of variance with SPSS (version 13.0; SPSS, Chicago). The analysis of variance (ANOVA) was made at $P \leq 0.05$ and $P \leq 0.001$, and was used to assess the significance of 
Table 3. Histological variables studied to assess changes in cell/tissue organization of the graft interface of 5-month-old grafts in plum/plumcompatible homografts and compatible and incompatible heterografts of peach/plum. Existence or absence of the variable is indicated by + or - , respectively.



${ }^{\mathrm{z}} \mathrm{Cb}$ * in Figs. 1 and 2.

y Percentage of similarity of traits was calculated using the homograft 'PM 105 AD'/'PM 105 AD' as a reference.

peroxidase activity and peroxidase isozyme profile. Isozyme band position was assessed by Carnoy (version 2.1; Laboratory of Plant Systematics, Katholieke Universiteit Leuven, Leuven, Belgium). Mean separation was effectuated by Duncan's test and results shown are mean values $\pm \mathrm{SE}$.

\section{Results}

Cell and tissue structural organization at THE graft UNION. The rate of bud-take differs from homografts ('Myrobalan GF 3-1'/'Myrobalan GF 3-1' and 'PM 105 AD'/PM 105 AD') to heterografts (compatible 'Summergrand'/'PM 105 $\mathrm{AD}$ ' and incompatible 'Summergrand'/'Myrobalan GF 3-1') and oscillates from $70 \%$ to $100 \%$. Graft interface was continuous in all combinations, indicating good graft establishment in the three types of grafts (Table 3). Lacuna was observed in the interface of the homograft 'Myrobalan GF 3-1', corresponding to the delay in callus bridge formation. Changes related to incompatibility between different types of combinations were mainly expressed in cambial and vascular tissues. The major differences found in the histological study at the interface level, related to cambium and vascular organization, are summarized in Table 3. Because the percentage of similarity of all traits investigated was high $(90 \%-100 \%)$ between homografts and compatible heterografts, only data corresponding to heterografts are presented in Figs. 1 and 2.

The interface was identified by a line delimiting scion from rootstock tissues, which was strongly stained with Toluidine Blue $\mathrm{O}$ or by a layered zone between the two components, which stick the grafted tissues together. The over-stained line was slightly apparent and discontinuous in the compatible combination (arrowheads in Fig. 1, A and B). However, for incompatible combinations, the line was emergent and continuous (arrowheads in Fig. 2A, arrow in Fig. 2D). In the central part of the graft, the two partners cohered by a multiplication of callus cells (Figs. 1A and 2A).

Compatible combinations showed organized and homogenous arrangement of cambium cells in the contact interface (Fig. 1, A and B). In contrast, cambium cells in the incompatible interface showed a disorganized arrangement. Islands of


Fig. 1. Graft interface structure of peach/plum ('Summergrand'/'PM 105 AD')compatible combination in transversal sections of grafts. (A) Compatible overstaining line delimited stock from scion (arrowheads). Proliferation and differentiation in new vascular cells of cambium between the two grafted components. Arrows indicate tracheary elements. (B) Reabsorption of overstaining line (arrowhead). Differentiation of wood rays in graft interface (arrows). (C) Complete differentiation of scion phloem delimited by adjacent rays (ph unit). Wood rays differentiation (arrows). (D) Details of the scion phloem structure; $\mathrm{Cb}=$ cambium, $\mathrm{Cb}^{*}=$ cambium differentiated into vascular tissues, $\mathrm{ph}=$ phloem, $\mathrm{pr}=$ wood rays $(=$ parenchymatous rays $=$ xylem rays $)$, $\mathrm{Rs}=$ rootstock, $\mathrm{Sc}=$ scion, $\mathrm{se}=$ sieve elements, $\mathrm{V}=$ vessels; bar $=20 \mu \mathrm{m}$. 

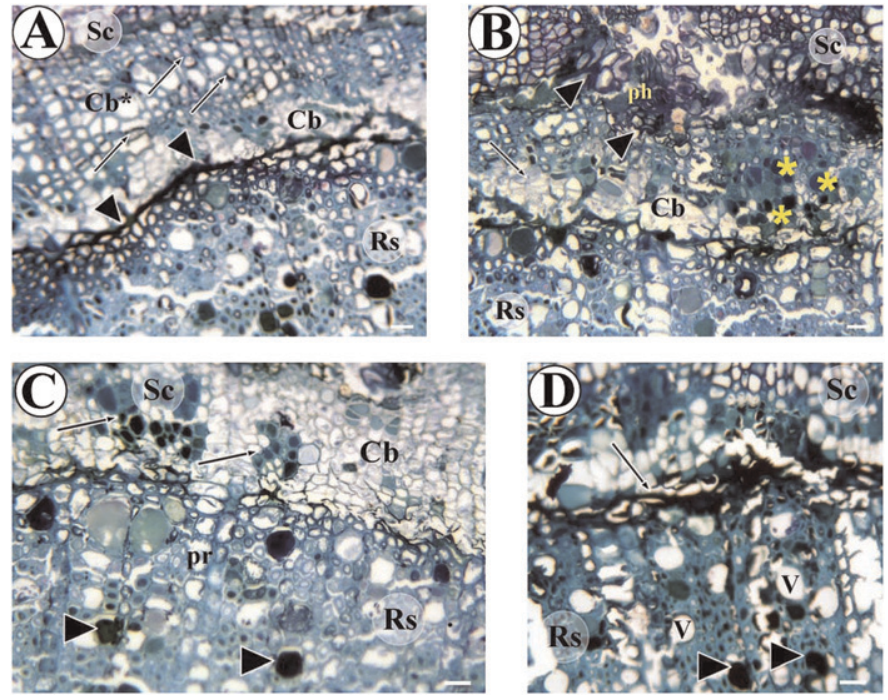

Fig. 2. Transversal sections of graft interface structure of peach/plum ('Summergrand'/'Myrobalan GF 3-1')-incompatible combination. (A) Incompatible continuous overstaining line delimited stock from scion (arrowheads). Proliferation and differentiation in new vascular cells of cambium between the two grafted components. $\mathrm{Cb}^{*}$ indicates that cambium is being differentiated into vascular cells. Arrows indicate the presence of tracheary elements. (B) Cell cambium disorganization (arrow). Cambium cell vacuoles stained in blue-green color showing the presence of phenolic compounds (asterisks). Phloem disorganization and degeneration (arrowheads). (C) Cambium before differentiation into vascular tissues. Phenolic compound accumulation in the cambial region (arrows). Wood ray proliferation (pr). Tylosis reaction (arrowheads). (D) Vast degeneration of vessels by tylosis reaction (arrowheads). Overstaining line persisting between two components (arrow); $\mathrm{Cb}=$ cambium, $\mathrm{Cb}^{*}=$ cambium differentiated into vascular tissues, $\mathrm{ph}=$ phloem, $\mathrm{pr}=$ wood rays $(=$ parenchymatous rays $=$ xylem rays $), \mathrm{Rs}=$ rootstock, $\mathrm{Sc}=$ scion, $\mathrm{V}=$ vessels; bar $=9 \mu \mathrm{m}$.

dark-staining phenolic compounds in vacuoles of cambium cells were regularly observed at the graft interface (asterisk in Fig. 2B, arrows in Fig. 2C). Invagination of the cambium was slightly observed in incompatible grafts (data not shown). In some areas of incompatible grafts, a lesser amount of new differentiated vascular cells was noted compared with compat- ible interfaces (Cb* in Figs. 1A and 2A, Cb in Fig. 2C). Sieve elements were easily identified in compatible grafts and showed a good vascular connection establishment and proper phloem ray arrangement and structure (phloem unit in Fig. 1C, "se" and arrowhead in Fig. 1D). In apart, in the incompatible grafts, we observed phloem structural disorders (arrowheads in Fig. 2B) and discontinuities (see absence of vascular connection continuity in Table 3 ).

Wood vascular connections were observed in both combinations (Table 3), but they were more evident in compatible combinations with the presence of tracheae elements in new vascular cells (arrows in Figs. 1A and 2A). Note the degeneration of vessels in xylem in the incompatible combinations, indicating a tylosis reaction (arrowheads in Fig. 2, C and D). At this stage of graft development, it was difficult to identify the cells that emerged from the scion and those emerging from the stock, for both graft combinations. Only when it was present did the over staining line allow us to determine the graft interface.

Peroxidase activity. As shown in Table 4, incompatible combinations of 'Summergrand' grafted on 'Damas GF 1869', 'Krymsk-1', 'Marianna 2624', 'Marianna GF 8-1', and 'Myrobalan GF 3-1' rootstocks exhibited higher peroxidase activities during dormancy and vegetative growth periods when compared with compatible grafts. Peroxidase activity of incompatible combinations significantly differs from compatible combinations $(P \leq 0.05)$. Graft combinations that first showed some symptoms of translocated incompatibility at the beginning of the summer exhibited the highest peroxidase activity at dormancy and over the vegetative period (Table 4). This was the case for the combination 'Summergrand'/'Damas GF 1869' that maintained the highest peroxidase activity, with such a tendency being maintained during the vegetative period. With compatible and incompatible combinations, the rate of peroxidase activity during dormancy was also higher than during the vegetative growth season (Table 4).

Peroxidase isozyme profile. Profiles of isoperoxidase of nonbudded scions and rootstocks revealed some differences among Prunus rootstocks (Fig. 3). Conversely, the isoperoxidase profiles of peach and nectarine scions used in this study

Table 4. Peroxidase activity in dormancy and vegetative periods of graft union of 'Summergrand' nectarine grafted on different Prunus rootstocks.

\begin{tabular}{|c|c|c|c|c|}
\hline \multirow[b]{2}{*}{ Rootstock } & \multicolumn{2}{|c|}{ Peroxidase activity $\left[\right.$ mean \pm SE $\left.\left(\mu \mathrm{mol} \cdot \mathrm{min}^{-1} \cdot \mathrm{g}^{-1} \mathrm{FW}\right)\right]$} & \multirow[b]{2}{*}{ Compatibility $^{z}$} & \multirow[b]{2}{*}{$P^{\mathrm{y}}$} \\
\hline & Dormancy period & Vegetative period & & \\
\hline \multicolumn{5}{|l|}{ Peach-based rootstocks } \\
\hline 'Barrier' & $17.7 \pm 0.3 \mathrm{a}^{\mathbf{x}}$ & $4.3 \pm 0.6 \mathrm{a}$ & Compatible & $* * *$ \\
\hline 'GF 677' & $18.5 \pm 0.1 \mathrm{a}$ & $4.7 \pm 0.1 \mathrm{a}$ & Compatible & $* * *$ \\
\hline \multicolumn{5}{|l|}{ Plum-based rootstocks } \\
\hline 'Adesoto 101' & $18.6 \pm 0.1 \mathrm{a}$ & $4.7 \pm 0.4 \mathrm{a}$ & Compatible & $* * *$ \\
\hline 'Ishtara ${ }^{\circledR}$ Ferciana' & $18.3 \pm 0.4 \mathrm{a}$ & $4.4 \pm 0.3 \mathrm{a}$ & Compatible & $* * *$ \\
\hline 'Damas GF 1869' & $25.0 \pm 0.5 \mathrm{c}$ & $12.6 \pm 0.3 \mathrm{~d}$ & Incompatible & $* * *$ \\
\hline 'Krymsk-1' & $24.4 \pm 0.3 \mathrm{bc}$ & $7.4 \pm 0.1 \mathrm{c}$ & Incompatible & $* * *$ \\
\hline 'Marianna 2624' & $24.1 \pm 0.3 \mathrm{bc}$ & $6.4 \pm 0.3 b$ & Incompatible & $* * *$ \\
\hline 'Marianna GF 8-1' & $23.6 \pm 0.5 b$ & $6.6 \pm 0.1 \mathrm{bc}$ & Incompatible & $* * *$ \\
\hline 'Myrobalan GF 3-1' & $23.8 \pm 0.1 \mathrm{~b}$ & $7.1 \pm 0.5 \mathrm{bc}$ & Incompatible & $* * *$ \\
\hline
\end{tabular}

${ }^{\mathrm{z} C o m p a t i b i l i t y ~ p e r f o r m a n c e ~ o f ~ r o o t s t o c k s ~ w i t h ~ ' S u m m e r g r a n d ' ~ n e c t a r i n e . ~}$

${ }^{\mathrm{y}}$ Mean separation between the two treatment periods was performed by $t$ test at $P \leq 0.05(\mathrm{n}=3)$; *** indicates significance at $P \leq 0.001$.

${ }^{x}$ Mean separation within columns by Duncan's multiple range tests at $P \leq 0.05(\mathrm{n}=3)$. 


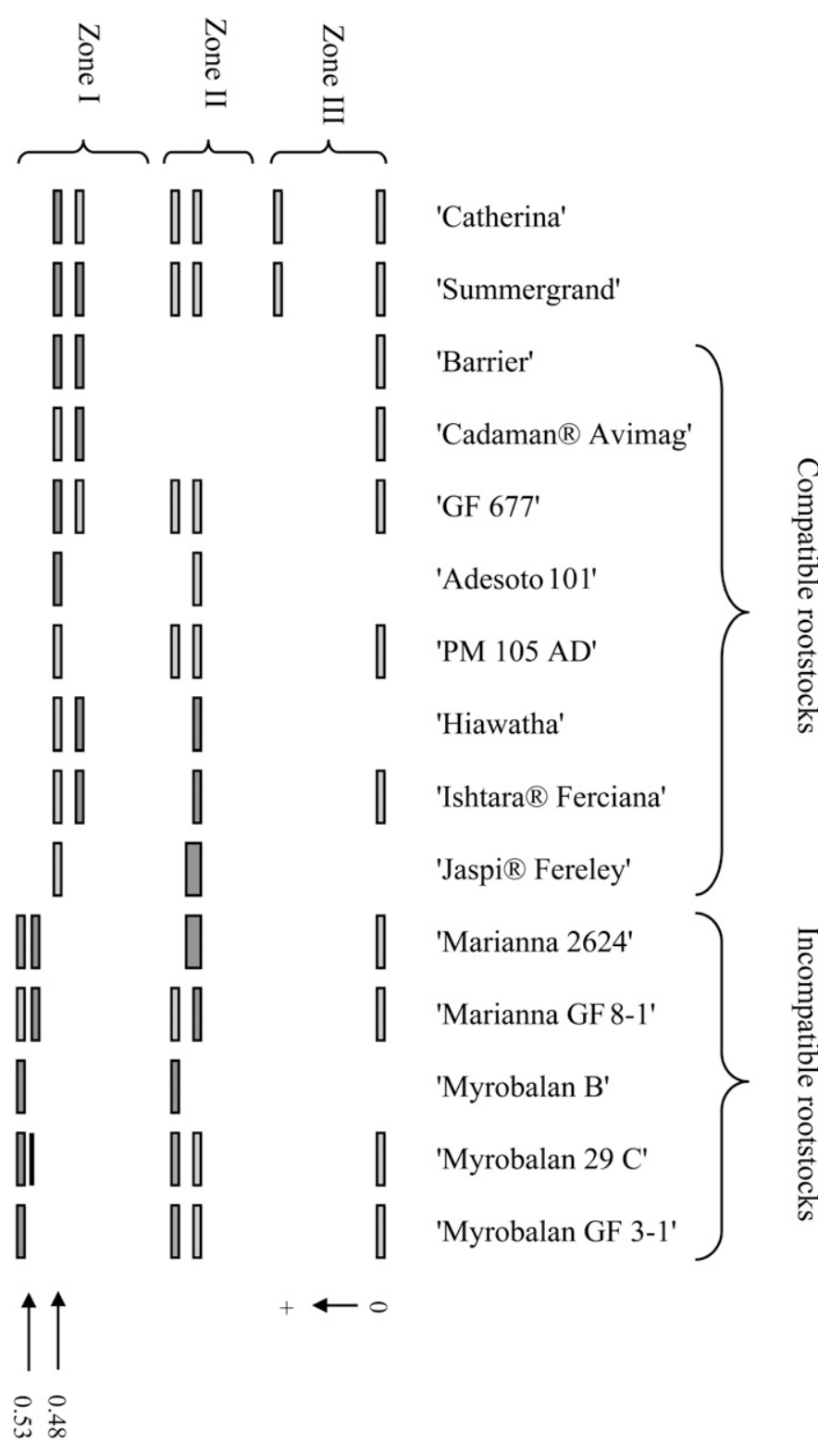

Fig. 3. Zymograms for peroxidase of nonbudded samples of 'Catherina' peach and 'Summergrand' nectarine scions, and compatible and incompatible Prunus rootstocks. Isozyme profile is divided in three zones of activity: Zone I, Zone II, and Zone III from the most anodal $(+)$ to the most cathodal one $(-)$. Arrow represents migration of the proteins in the gel. Only the anodal zone (Zone I) is considered in this study because these peroxidases may be related to graft compatibility.

were identical. To facilitate the study, isozyme profile was divided in three zones of activity: Zone I, Zone II, and Zone III, from the most anodal to the most cathodal one. Only the anodal zone (Zone I) was considered in this study because these peroxidases could regulate lignification and may be related to graft compatibility (Buchloh, 1960; Catesson et al., 1986). Analysis of gel profiles of Zone I showed an isoperoxidase band $(\mathrm{Rf}=0.48)$ that was present in peach and nectarine cultivars, as well as in the compatible peach- and plum-based rootstocks. Another isoperoxidase band $(\mathrm{Rf}=0.53)$ was present only in the incompatible plum-based rootstocks (Fig. 3). In addition, we studied the isozyme profiles of the graft union only in compatible ('Summergrand'/'PM 105 AD') and incompatible heterograft
('Summergrand'/'Myrobalan GF 3-1'). Results showed that the phenotype was additive in Zone I in compatible and incompatible combinations used in this study (data not shown). In the incompatible combination, the isozyme profile showed that in Zone II, one band of the scion disappeared when it was grafted on the 'Myrobalan GF 3-1' rootstock (data not shown).

\section{Discussion}

In this study, we describe a method for early graft incompatibility detection at dormancy based on cellular organization and peroxidase activity assessment and profile studies.

Our results confirmed that there are visible differences in the structural organization of cells and tissues of compatible versus incompatible grafts in 5-month-old peach grafts. Differences were exclusively located at the scion/rootstock interface mainly in cambium and vascular components, as has already been mentioned by other authors (Ermel et al., 1997, 1999). In line with previous reports for woody (Deloire and Hébant, 1982; Ermel et al., 1997, 1999) and herbaceous species (Moore and Walker, 1981; Tiedemann, 1989; Wang and Kollmann, 1996), stock and scion were delimited by an over-stained line. The arrangement of the cambium cells was less organized in graft interface of the incompatible combinations according to previous reports about apricot [Prunus armeniaca (Errea et al., 2001)] and pear (Ermel et al., 1997). This supports that cambium cell disorganization is an early indicator of graft incompatibility.

In 5-month-old unions, differentiated phloem was observed, while xylem differentiation was incomplete in compatible and incompatible combinations. Previous studies on conifers in Abies sachalinensis reported the capacity of cells to initiate the formation of phloem before cambial reactivation and xylem differentiation (Oribe et al., 2003). In contrast with the findings of Moing and Carde (1988) on peach/plum combinations, but in line with reports for pear (Moore, 1984) and herbaceous species (Moore and Walker, 1981), phloem tissue degeneration and disorganization in some graft interface areas were observed in the incompatible grafts (ph in Fig. 2B). Wood vascular connection was observed in the compatible combinations. In turn, as it was already reported in pear (Espen et al., 2005), incompatible grafts showed less tracheary elements (Fig. 2A).

In the present study, xylem vessel degeneration was noted in the incompatible combinations (Fig. 2, C and D) and was characterized by a tylosis reaction (Fahn, 1982). Tylosis impairs water transport and mineral element assimilation by injuring vessels (Sperry, 2003), which may explain the reduction of growth of incompatible trees (Soumelidou et al., 1994; Zarrouk et al., 2006). Our results support the suggestion of using vascular tissue disorders in graft interface between scion and stock at 5 months after grafting, as an indicator for early assessment of graft incompatibility. The abnormal accumulation of phenols at the incompatible graft interface was previously reported in cherry [Prunus avium (Gebhardt and Feucht, 1982; Usenik and Stampar, 2001)], pear (Ermel et al., 1999), apricot (Errea et al., 1994, 2001), pepper [Capsicum annuum (Deloire and Hébant, 1982)], and, more recently, in Upaca kirkiana (Mng'omba et al., 2008). Our results (Fig. 2, B and $\mathrm{C}$ ) suggest that accumulation of phenolic compounds in the cambium cell interface of incompatible peach/plum combinations is also related to graft incompatibility and may avoid the establishment of the union between scion and rootstock by 
inhibiting the lignification of cells (Gur and Blum, 1973) and consequently impairing a good union.

The dramatic presence of phenolic compounds in the incompatible graft interface may explain the high peroxidase activity found in the graft union because peroxidases are related to the oxidation of phenolic compounds (Takahama and Oniki, 1997). Differences in peroxidase activity between compatible and incompatible combinations were previously commented upon cherry during the first 3 weeks after grafting and its restoration 7 to 8 weeks after grafting (Schmid and Feucht, 1985). However, we observed that differences in peroxidase activities were maintained 5 to 7 months after grafting until the next vegetative period (Table 4 ). The higher peroxidase activity in the incompatible graft unions compared with compatible ones may explain cell degeneration in the graft interface and may justify the histological and vascular anomalies of connections found in the present study. Copes (1970) related cell necrosis in douglas-fir (Pseudotsuga menziesii) to the increase of peroxidase activity. Moreover, Gebhardt and Feucht (1982) associated the increase of peroxidase activity in cherry to a delay on xylem and phloem differentiation. The peroxidase activities of the incompatible 'Summergrand'/'Damas GF 1869' combination were significantly higher than the other values reported for incompatible combinations during dormancy and the vegetative period. This incompatible combination was the first to show an acute translocated incompatibility at the beginning of the summer. This supports the close relationship between peroxidase activity and the level of pear/quince compatibility as already observed by Musacchi et al. (2002). This finding suggested the determination of peroxidase activity at the graft union as an indicator for early detection of graft incompatibility.

The significant differences $(P \leq 0.001)$ in peroxidase activities between dormancy and vegetative growth periods (Table 4) found herein can probably be explained by their role on defense mechanisms against frost stress (Citadin et al., 2002; Szalay et al., 2005). Dissimilarities in the isoperoxidase composition between stock and scion might result in abnormal lignification and lack of vascular connection at the graft union (Santamour, 1988c). Results of the present study are in accordance with Santamour (1988a, 1988b, 1988c). Peroxidases are a large family of isozymes with an extreme range of isoelectric point, serving a multitude of functions. Evidence showed that the activity of four basic isoperoxidases in castor bean [Ricinus communis (Bruce and West, 1989)] and one basic isoperoxidase in the pear/quince graft combination have correlated to lignin deposition (Gulen et al., 2002).

Therefore, in the present study, it was suggested that the absence of a band with $\mathrm{Rf}=0.48$ in the incompatible rootstocks (Fig. 3) might be associated with graft incompatibility in peach/ plum combinations. This band was only present in compatible rootstocks and scions. Several isoperoxidases are involved in the production of different structural lignins that can have different binding characteristics (Santamour, 1988c) and can be associated with abnormal peroxidase activity at the graft interface, as observed for incompatible unions. The preliminary study on the isozyme profile of the union showed a difference between compatible and incompatible grafts in Zones I and II. It was found that in the compatible union ('Summergrand'/'PM 105 AD'), the isoperoxidase profile in Zone I was an addition of scion and stock isozyme. In the incompatible union of 'Summergrand'/'Myrobalan GF 3-1', isozymes profiles were addi- tive in Zone I, but one band, present in both genotypes, disappeared in Zone II.

\section{Conclusion}

In the present investigation, it was possible to suggest a histological analysis and biochemical methods to detect early graft incompatibility in peach/plum combinations. The main symptoms found affecting cell organization were cambium cell disorganization, less differentiation of vascular tissues, degeneration of phloem and xylem cells, and accumulation of phenols at the graft interface in 5-month-old incompatible trees. In addition, peroxidase activity may be a good index for assessing graft incompatibility in the dormancy period, as well as in the vegetative growth period.

Isoperoxidase patterns of nonbudded scions and stocks can be used as a tool to predict early graft incompatibility and appeared to be promising because it would eliminate the need to wait for the appearance of symptoms of visual and anatomic abnormalities. Further studies are required to demonstrate the real implication of specific bands in the graft compatibilityincompatibility process.

\section{Literature Cited}

Arulsekar, S. and D.E. Parfitt. 1986. Isozyme analysis procedures for stone fruits, almond, grape, walnut, pistachio and figs. HortScience 21:928-933.

Beckman, T.G. and G.A. Lang. 2003. Rootstock breeding for stone fruits. Acta Hort. 622:531-551.

Breen, P.J. 1975. Effect of peach/plum graft incompatibility on seasonal carbohydrate changes. J. Amer. Soc. Hort. Sci. 100:253259.

Bruce, R.J. and C.A. West. 1989. Elicitation of lignin biosynthesis and isoperoxidase activity by pectic fragments in suspension cultures of castor bean. Plant Physiol. 91:889-897.

Buchloh, G. 1960. The lignification in stock-scion junctions and its relation to compatibility, p. 67. In: J.B. Pidham (ed.). Phenolics in plants in health and disease. Pergamon Press, Oxford, UK/New York. Byrne, D.H., T.A. Bacon, and J.N.A. Egilla. 1990. Patrones de frutales de hueso tolerantes a suelos calizos. Estado actual de los patrones frutales. Información Técnica Económica Agraria 9:117-133.

Cambra, R. 1990. Adafuel, an almond $\times$ peach hybrid rootstock. HortScience 25:584.

Catesson, A.M., A. Imberty, R. Goldberg, and Y. Czaninski. 1986. Nature, localization and specificity of peroxidases involved in lignification processes, p. 189. In: H. Greppin, C. Penel, and T. Gaspar (eds.). Molecular and physiological aspects of plant peroxidases. University of Geneva, Geneva, Switzerland.

Citadin, I., M.C.B. Raseira, E. Augustin, and F.G. Herter. 2002. Relationship of peroxidase, 6-phosphogluconate dehydrogenase and phosphoglucoisomerase to endodormancy phase in peach. Acta Hort. 592:451-457.

Copes, D.L. 1970. Initiation and development of graft incompatibility symptoms in douglas-fir. Silvae Genet. 19:101-107.

Deloire, A. and C. Hébant. 1982. Peroxidase activity and lignifications at the interface between stock and scion of compatible and incompatible grafts of Capsicum on Lycopersicon. Ann. Bot. (Lond.) 49:887-891.

Deloire, A. and C. Hébant. 1983. Le greffage des combinaisons compatibles et incompatibles du genre Prunus: Une étude histophysiologique de la zone de jonction. Agronomie 3:207-212.

Ermel, F.F., J. Kervella, A.M. Catesson, and J.L. Poëssel. 1999. Localized graft incompatibility in pear/quince (Pyrus communis/ Cydonia oblonga) combinations: Multivariate analysis of histological data from 5-month-old grafts. Tree Physiol. 19:645-654. 
Ermel, F.F., M. Faurobert, A.M. Catesson, and J.L. Poëssel. 1997. Early scion/stock junction in compatible and incompatible pear/pear and pear/quince grafts: A histological study. Ann. Bot. (Lond.) 79:505-515.

Errea, P., A. Felipe, and M. Herrero. 1994. Graft establishment between compatible and incompatible Prunus spp. J. Expt. Bot. 272:393-401.

Errea, P., L. Garay, and J.A. Marín. 2001. Early detection of graft incompatibility in apricot (Prunus armeniaca) using in vitro techniques. Physiol. Plant. 112:135-145.

Espen, L., M. Cocucci, and G.A. Sacchi. 2005. Differentiation and functional connection of vascular elements in compatible and incompatible pear/quince internode micrografts. Tree Physiol. 25:1419-1425.

Fahn, A. 1982. Secondary xylem, p. 310-350. In: S. Broido-Altman (ed.). Plant anatomy. Pergamon Press, Oxford, UK/New York.

Felipe, A.J. 2009. Felinem, Garnem, and Monegro almond $\times$ peach hybrid rootstocks. HortScience 44:196-197.

Fernández-García, N., M. Carvajal, and E. Olmos. 2004. Graft union formation in tomato plants: Peroxidase and catalase involvement. Ann. Bot. (Lond.) 93:53-60.

Feucht, W., P.P.S. Schmid, and E. Christ. 1983. Compatibility in Prunus avium/Prunus cerasus graftings during the initial phase. II. Reduction of cell number and peroxidases in the rootstock cambium. Scientia Hort. 21:225-231.

Gebhardt, K. and W. Feucht. 1982. Polyphenol changes at the union of Prunus avium/Prunus cerasus grafts. J. Hort. Sci. 57:253-258.

Gogorcena, Y., J. Abadía, and A. Abadía. 2004. A new technique for screening iron efficient genotypes in peach rootstocks elicitation of root ferric chelate reductase by manipulation of external iron concentrations. J. Plant Nutr. 27:1701-1715.

Gulen, H., R. Arrora, A. Kuden, S.L. Krebs, and J. Postman. 2002. Peroxidase isozyme profiles in compatible and incompatible pearquince graft combinations. J. Amer. Soc. Hort. Sci. 127:152-157.

Gur, A. and A. Blum. 1973. The role of cyanogenic glycoside in incompatibility between peach scions and almond rootstocks. Hort. Res. 13:1-10.

Gur, A., R.M. Samish, and E. Lifshitz. 1968. The role of the cyanogenic glycoside on the quince in the incompatibility between pear cultivars and quince rootstocks. Hort. Res. 8:113-134.

Harkin, J.M. and T.R. Obst. 1973. Lignification in trees: Indication of exclusive peroxidase participation. Science 180:296-297.

Hartman, H.T., D.E. Kester, F.T. Davies, and R. Geneve. 2002. Plant propagation: Principles and practices. 7th ed. Prentice Hall, Englewood Cliffs, NJ.

Herrero, J. 1951. Studies of compatible and incompatible graft combinations with special reference to hardy fruit trees. J. Hort. Sci. 26:186-237.

Jiménez, S., J. Pinochet, A. Abadía, M.A. Moreno, and Y. Gogorcena. 2008. Tolerance response to iron chlorosis of Prunus selections as rootstocks. HortScience 43:304-309.

Kester, D.E. and R.N. Asay. 1986. 'Hansen 2168' and 'Hansen 536': Two new Prunus rootstock clones. HortScience 21:331.

Manganaris, A.G. and F.H. Alston. 1992. Inheritance and linkage relationships of peroxidase isozymes in apple. Theor. Appl. Genet. 83:392-399.

Mng'omba, S.A., E.S. du Toit, and F.K. Akinnifesi. 2008. Early recognition of graft compatibility in Uapaca kirkiana Müell Arg. clones, provenances and species. Agrofor. Syst. 74:173-183.

Moing, A. and J.P. Gaudillère. 1992. Carbon and nitrogen partitioning in peach/plum grafts. Tree Physiol. 10:81-92.

Moing, A. and P. Carde. 1988. Growth, cambial activity and phloem structure in compatible and incompatible peach/plum grafts. Tree Physiol. 4:347-359.

Moing, A., G. Salesses, and P.H. Saglio. 1987. Growth and the composition and transport of carbohydrate in compatible and incompatible peach/plum grafts. Tree Physiol. 3:345-354.

Moore, R. 1984. A model for graft compatibility-incompatibility in higher plants. Amer. J. Bot. 71:752-758.
Moore, R. and D.B. Walker. 1981. Studies of vegetative compatibilityincompatibility in higher plants: II. A structural study of an incompatible heterograft between Sedum telefoides (Crassulaceae) and Solanum pennelli (Solanaceae). Amer. J. Bot. 68:831-842.

Moreno, M.A., A. Moing, M. Lansac, J.P. Gaudillère, and G. Salesses. 1993. Peach/ myrobalan plum graft incompatibility in the nursery. J. Hort. Sci. 68:705-714.

Moreno, M.A. and R. Cambra. 1994. Adarcias: An almond $\times$ peach hybrid rootstock. HortScience 29:925.

Moreno, M.A., J.P. Gaudillère, and A. Moing. 1994a. Protein and amino acid content in compatible and incompatible peach/plum grafts. J. Hort. Sci. 69:955-962.

Moreno, M.A., M.C. Tabuenca, and R. Cambra. 1994b. Performance of Adafuel and Adarcias as peach rootstocks. HortScience 29:1271-1273.

Moreno, M.A., M.C. Tabuenca, and R. Cambra. 1995. Adesoto 101, a plum rootstock for peaches and other stone fruit. HortScience 30:1314-1315.

Mosse, B. 1962. Graft-incompatibility in fruit trees. Tech. Commun. Bul. Hort. East Malling 28:36.

Musacchi, S., A. Masia, and J. Fachinello. 2002. Variation of some enzymatic activities in relationship to scion/stock compatibility in pear/quince combinations. Acta Hort. 596:389-392.

Nicotra, A. and L. Moser. 1997. Two new rootstocks for peach and nectarines. Penta and Tetra. Acta Hort. 451:269-271.

O’Brien, T.P., N. Feder, and M.E. McCully. 1965. Polychromatic staining of plant cell walls by Toluidine Blue O. Protoplasma 59:367-373.

Okie, W.R. and J.H. Weinberger. 1996. Plums, p. 559-607. In: J. Janick and N. Moore (eds.). Fruit breeding. Vol I.Tree and tropical fruits. Wiley, New York.

Oribe, Y., R. Funada, and T. Kubo. 2003. Relationships between cambial activity, cell differentiation and the localization of starch in storage tissues around the cambium in locally heated stems of Abies sachalinensis (Schmidt) masters. Trees (Berl.) 17:185-192.

Pinochet, J. 2009. Greenpac, a new peach hybrid rootstock adapted to Mediterranean conditions. HortScience 44:1456-1457.

Pinochet, J., C. Calvet, A. Hernández-Dorrego, A. Bonet, A. Felipe, and M. Moreno. 1999. Resistance of peach and plum rootstocks from Spain, France, and Italy to root-knot nematode Meloidogyne javanica. HortScience 34:1259-1262.

Rodrigues, C.A., L. Bender Machado, A. Campos Diniz, J. Carlos Fachinello, and G. Renan De Luces Fortes. 2002. Peroxidases e fenóis totais em tecidos de porta-exertos de Prunus sp. nos periódos de crecimiento vegetativo e de dormência. Ciência Rural 4:559-564.

Rowe, R.N. and D.V. Beardsell. 1973. Waterlogging of fruit trees. Hort. Abstr. 43:534-548.

Royo, J.B., F. Cabello, S. Miranda, Y. Gogorcena, J. González, S. Moreno, R. Itoiz, and J.M. Ortiz. 1997. The use of isozymes in characterization of grapevines (Vitis vinifera L.). Influence of the environment and time of sampling. Scientia Hort. 69:145-155.

Santamour, F.S. 1988a. Graft incompatibility related to cambial peroxidase isozymes in chinese chestnut. J. Environ. Hort. 6:33-39.

Santamour, F.S. 1988b. Graft incompatibility related to cambial peroxidase isozymes in red oak. J. Environ. Hort. 6:87-93.

Santamour, F.S. 1988c. Graft incompatibility in woody plants: An expanded perspective. J. Environ. Hort. 6:27-32.

Santamour, F.S. 1992. Predicting graft incompatibility in woody plants. Combined Proc. Intl. Plant Propagators Soc. 42:131-134.

Schmid, P.P.S. and W. Feucht. 1981. Differentiation of sieve tubes in compatible and incompatible Prunus graftings. Scientia Hort. 15:349-354.

Schmid, P.P.S. and W. Feucht. 1985. Compatibility in Prunus avium/ Prunus cerasus graftings during the initial phase. III. Isoelectrofocusing of proteins, peroxidases and acid phosphatases during union formation. J. Hort. Sci. 60:311-318.

Soumelidou, K., N.H. Battey, P. John, and J.R. Barnett. 1994. The anatomy of the developing bud union and its relationship to dwarfing in apple. Ann. Bot. (Lond.) 74:605-611. 
Sperry, J.S. 2003. Evolution of water transport and xylem structure. Int. J. Plant Sci. 164:S115-S127.

Sterjiades, R., J.F.D. Dean, G. Gamble, D.S. Himmelsbach, and K.E.L. Eriksson. 1993. Extracellular laccases and peroxidases from sycamore maple (Acer pseudoplatanus) cell suspension cultures. Reactions with monolignols and lignin model compounds. Planta 190:75-87.

Szalay, S., A. Hegedus, and E. Stefanovits-Banyai. 2005. Presumable protective role of peroxidase and polyphenol oxidase enzymes against freezing stress in peach (Prunus persica (L.) Batsch). Acta Biologica Szegediensis 49:121-122.

Takahama, U. and T. Oniki. 1997. A peroxidase/phenolics/ascorbate system can scavenge hydrogen peroxide in plant cells. Physiol. Plant. 101:845-852.

Tiedemann, R. 1989. Graft union development and symplastic phloem contact in the heterograft Cucumis sativus on Cucurbita ficifolia. J. Plant Physiol. 134:427-440.
Usenik, V. and F. Stampar. 2001. Different rootstocks for cherries: Influence on polyphenol content and graft incompatibility. Acta Hort. 557:175-179.

Wang, Y. and R. Kollmann. 1996. Vascular differentiation in the graft union of in vitro grafts with different compatibility. Structural and functional aspects. J. Plant Physiol. 147:521-533.

Wertheim, S.J. and A.D. Webster. 2005. Rootstocks and interstems, p. 156-175. In: J. Tromp, A.D. Webster, and S.J. Wertheim (eds.). Fundamentals of temperate zone tree fruit production. Backhuys Publishers, Leiden, The Netherlands.

Zarrouk, O., J. Pinochet, Y. Gogorcena, and M.A. Moreno. 2006. Graft compatibility between peach cultivars and Prunus rootstocks. HortScience 41:1389-1394.

Zarrouk, O., Y. Gogorcena, J. Gómez-Aparisi, J.A. Betrán, and M.A. Moreno. 2005. Influence of almond $\times$ peach hybrids rootstocks on flower and leaf mineral concentration, yield and vigour of two peach cultivars. Scientia Hort. 106:502-514. 